\title{
Towards groundwater neutral cropping systems in the Alluvial Fans of the North China Plain
}

\author{
P.A.J. van Oort ${ }^{\mathrm{a}, \mathrm{b}, *, 1}$, G. Wang ${ }^{\mathrm{c}, 1}{ }^{,}$, J. Vos ${ }^{\mathrm{a}}$, H. Meinke ${ }^{\mathrm{a}, \mathrm{d}}$, B.G. Li ${ }^{\mathrm{e}}$, J.K. Huang ${ }^{\mathrm{f}}$, \\ W. van der Werf ${ }^{a}$ \\ a Wageningen University, Plant Sciences, Centre for Crop Systems Analysis, Crop and Weed Ecology Group, P.0. Box 430, 6700 AK, Wageningen, The \\ Netherlands \\ ${ }^{\mathrm{b}}$ Africa Rice Center (AfricaRice), 01 BP 2031 Cotonou, Benin \\ ' Faculty of Agronomy, Agricultural University of Hebei, Baoding, Hebei 071001, China \\ d School of Land and Food, University of Tasmania, Hobart, TAS 7001, Australia \\ e College of Resources and Environment, China Agricultural University, China \\ ${ }^{\mathrm{f}}$ Center for Chinese Agricultural Policy, Chinese Academy of Sciences Institute of Geographic Sciences and Natural Resources Research, China
}

\section{A R T I C L E I N F O}

\section{Article history:}

Received 28 May 2015

Received in revised form 6 November 2015

Accepted 7 November 2015

Available online 7 December 2015

\section{Keywords:}

Groundwater

North China Plain

Sustainable

Crop rotation

Wheat

Maize

Plastic film mulch

APSIM

\begin{abstract}
A B S T R A C T
Groundwater levels in the North China Plain (NCP), the bread basket of China, have dropped more than one meter per year over the last 40 years, putting at risk the long term productivity of this region. Groundwater decline is most severe in the Alluvial Fans where our study site is located. Avoiding a foreseeable systems collapse requires region-wide changes in crop systems management, underpinned by sound environmental policies. Here, we explore the potential of crop system adaptation to remedy the excessive water use and quantify the likely yield penalties associated with more sustainable water use practices. Using simulations with the APSIM cropping systems model we explore production opportunities in an area within the NCP with intensive cropping and no access to irrigation from rivers. We estimate the attainable production levels for wheat and maize if agriculture were made groundwater neutral, through changes in crop sequence, irrigation practices and water conservation technologies (e.g. mulching with plastic film). Total grain production would drop by $44 \%$ compared to current practice if agriculture were made groundwater neutral. Water conservation by plastic film could limit this reduction to 21-33\% but possible environmental impacts of plastic film need attention. This analysis facilitates a much needed debate on alternative agronomic practices and incentives through a quantitative comparison of adaptation options. Our biophysical analysis needs to be complemented with socio-economic considerations and discussions with all stakeholders. Similar analyses in other parts of the NCP are possible but require more accurate modelling of landscape hydrology and (towards the coast) risk of salt water intrusion.
\end{abstract}

(C) 2015 Published by Elsevier B.V.

\section{Introduction}

Just like many in the western world have been borrowing too much from the bank leading to the recent financial crisis, Chinese farmers in the North China Plain (NCP) are borrowing too much groundwater. A resource built up over hundreds of years is depleted within a few decades, and climate change could greatly influence

\footnotetext{
* Corresponding author at: Wageningen University, Plant Sciences, Centre for Crop Systems Analysis, Crop and Weed Ecology Group, P.O. Box 430, 6700 AK, Wageningen, The Netherlands. Fax: +31 317485572.

E-mail addresses: p.vanoort@cgiar.org, pepijn.vanoort@wur.nl (P.A.J.van Oort).

1 Both authors of P.A.J. van Oort and G. Wang contributed equally as first authors of this paper.
}

the water cycle and aggravate the water crisis situation in the NCP (Changming et al., 2001; Qiu, 2010; Tao et al., 2003; Tao et al., 2005; Xiong et al., 2009). Groundwater overexploitation is unsustainable, whether in the NCP or other parts of the world (Giordano 2009; Gleick and Palaniappan, 2010). The current practice will have to come to an end in the foreseeable future. Energy costs for pumping up the water increase with groundwater table depth. On the east coast, overdraft of groundwater already causes seawater intrusion into fresh water reservoirs (Xue et al., 2000). Furthermore, groundwater from deep aquifers can contain toxic levels of fluoride and arsenic (Currell et al., 2012). Health problems may therefore increase as pumping reaches into deeper layers. It is unclear when water extraction will become economically or practically impossible, but this moment is approaching. Once water resources are depleted, there will be no more "life-saving" irrigation possible in 


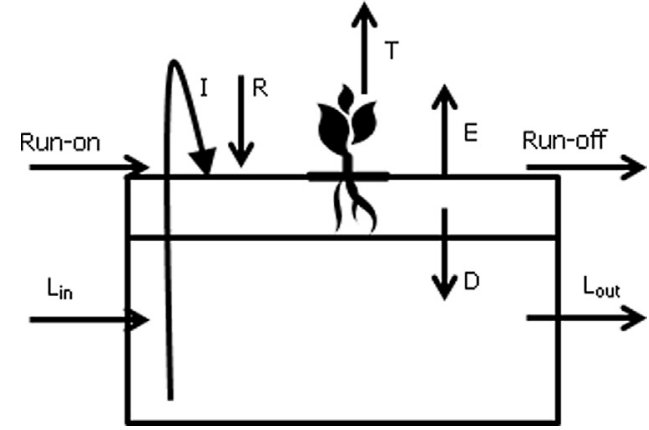

Fig. 1. Water balance. $I=$ irrigation (from groundwater), $R=$ rainfall, $T=$ transpiration, $E=$ evaporation, $D=$ drainage below the rootzone. $\Delta L=L_{\text {in }}-L_{\text {out }}=$ net lateral inflow underground. Net groundwater recharge is $D+\Delta L-I$.

the dry years, no bank to provide a loan to help us through the dry years. This is especially serious in the context of monsoonal climate variability, which can experience extended periods of drought, as was for instance witnessed in the Sahel region in Africa in the 1970s and 1980s (Shanahan et al., 2009).

Groundwater extraction must be drastically reduced to conserve the aquifers, and this would inevitably cause a large drop in production in the North China Plain (Wang et al., 2008). However, continuation of overusing the groundwater now will affect future generations who would have reduced access to groundwater, possibly none. Even though reductions of ground water use may seem socially and politically unacceptable now, it is critical to think about options to move towards a more sustainable system. Here, we have defined a sustainable system as one that does not deplete the groundwater on average over an extended number of years, i.e. where in the long term groundwater storage does not change.

To calculate the input/output balance of the water resource in aquifers, we consider the water extraction for irrigation $(I)$ as output, and drainage below the root zone $(D)$ and net lateral underground flow ( $\Delta L=L_{\text {in }}-L_{\text {out }}$ ) as inputs (Fig. 1). The groundwater table remains at the same level (neutral) if $I=D+\Delta L$ and groundwater declines if $I>D+\Delta L$. Run-on, run-off and the difference between soil moisture at the start and end of a simulation are of no significance on longer time scales and are therefore not considered in our study.

The simplest solution to stop groundwater decline is reducing irrigation input $(I)$. But often this also leads to reduced drainage $(D)$ so that the net effect is that groundwater levels keep going down (Kendy, 2003; Kendy et al., 2003, 2004). Hence, irrigation needs to be reduced by a greater amount than the current net extraction from ground water. We therefore consider the full water balance, which includes the rainfall $(R)$, evaporation $(E)$, transpiration $(T)$, run-on, run-off and the difference between soil moisture at the start and end of a 50 years (1961-2011) simulation (Fig. 1).

Another much studied solution to growing water scarcity is improving water use efficiencies (Condon et al., 2004; Fang et al., 2010; Xue et al., 2000; Zhang et al., 1999, 2003, 2006). Increased water use efficiencies are obtained by having a greater share of the water input ( $I$ or $I+R)$ taken up by the crop $(T)$ and less "lost" through drainage $(D)$ or evaporation $(E)$. However, if at unchanged irrigation input the drainage is reduced, then increased water use efficiencies will actually speed up groundwater decline. Increasing efficiency is therefore not a sufficient solution to the problem of declining water resources (Kendy 2003; Kendy et al., 2003, 2004).

A third possible management option is to not irrigate at all. Zero irrigation would eventually lead to increases in the groundwater table: in wet years part of the rainfall will drain below the root zone, replenishing the aquifer. However, the yield penalties of zero irrigation are very large (Wang et al., 2008). An important question is how much groundwater can be extracted annually while maintaining a neutral or slightly positive, long term downward water flux. Such baseline quantification is essential to determine sustainable irrigation levels. Best use of such irrigation can best be assessed via simulations (Chen et al., 2010a,b; Mao et al., 2005; Wang et al., 2008).

Under zero irrigation with rainfed agriculture, our study area has a small rainfall surplus (rainfall minus ET $>0$ ) and therefore a small lateral discharge to neighbouring aquifers and streams. Pumping decreases lateral discharge, because the hydraulic head at the pumping site becomes lower than that of neighbouring sites (Theis, 1940; Sophocleous, 2000; Bredehoeft, 2002; Devlin and Sophocleous, 2005; Zhou, 2009). The decrease will stop after some time in case of sustainable pumping rates so that a new equilibrium is installed, at which storage remains unchanged. "Sustainable pumping rates" are pumping rates at which groundwater storage remains unchanged in the long run (Devlin and Sophocleous, 2005; Zhou, 2009). Groundwater neutral cropping systems are cropping systems with sustainable pumping rates. The evapotranspiration (ET) differs between each cropping system, therefore each groundwater neutral cropping system has its own and different sustainable pumping rate. Our definition of sustainable pumping rates states that all rainfall received at a particular location may be consumed by evapotranspiration at the same location. As some of the rainfall infiltrates below the root zone in wet years (i.e. becomes gross recharge) we permit some pumping to recapture this part of the rainfall. But nothing more than that. Past pumping has already led to a drop from a net lateral outflow of around $42-53 \mathrm{~mm} /$ year to a net inflow of $16 \mathrm{~mm} / \mathrm{year}$. This reduction represents the water already captured from nearby aquifers. This deficit accumulated over a longer timespan cannot easily be undone (unless a purely rain-fed cropping system without any irrigation is adopted). At the very least, one should attempt not to further aggravate the situation. Therefore we allowed no further mining of nearby aquifers, something warned for by Sophocleous (2000). Therefore, we imposed the constraint of a constant (=not increasing) net lateral inflow $\Delta L$. With this constraint complex spatio-temporal modelling of groundwater dynamics is not needed and the analysis can be simplified to a simple water balance calculation.

With sustainable pumping rates the long run drainage plus net lateral underground flow equals the irrigation and evapotranspiration equals rainfall plus net lateral underground flow: $\Sigma(D+\Delta L)=\Sigma I$ and $\Sigma(E+T)=\Sigma(R+\Delta L)$. In this paper, we take 50 years as a summation period thus accounting for weather and high frequency climate variability (i.e. ENSO), but not for decadal and multi-decadal climate variability (Howden et al., 2007). Although simulation of climate change effects is not a key objective of this paper, we do include one climate change scenario to assess the sensitivity of our outcomes to future climate change.

The objective of this paper is to construct groundwater neutral cropping systems and compare these in terms of productivity and risk with the current unsustainable practice and with the possible future scenario when irrigation would no longer be possible. Sustainability is a broader concept than "sustainable pumping rates". Sustainability has many environmental and social dimensions, whereas "sustainable pumping rates" are simply those pumping rates at which groundwater storage does not change (Devlin and Sophocleous, 2005; Zhou, 2009). We follow this distinction in this paper. In Sections 2 and 3 we compare 3 cropping systems with current practice (declining water table), 8 cropping systems with sustainable pumping rates and 8 cropping systems with zero pumping rates. In Section 4 we place these in the broader perspective of sustainability. 

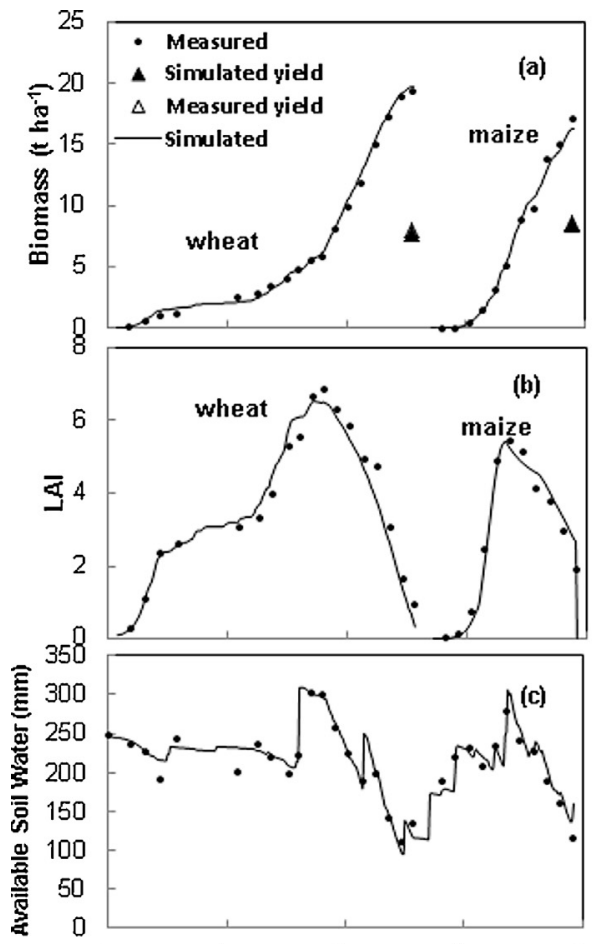

$101^{10100} \quad 810^{1107} \quad 810^{4107} \quad 710^{7107} \quad 5110100710106$
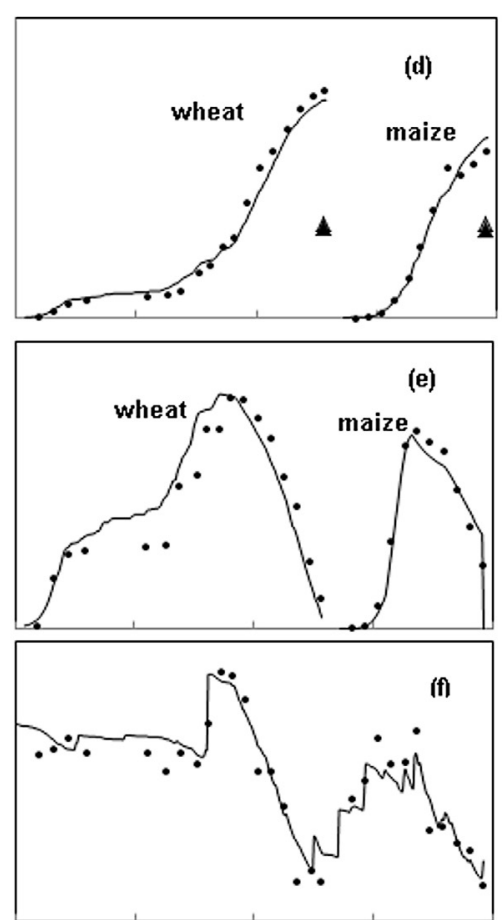

$0810^{4107} 0810^{4107} 07107107 \quad 05140107.1010106$
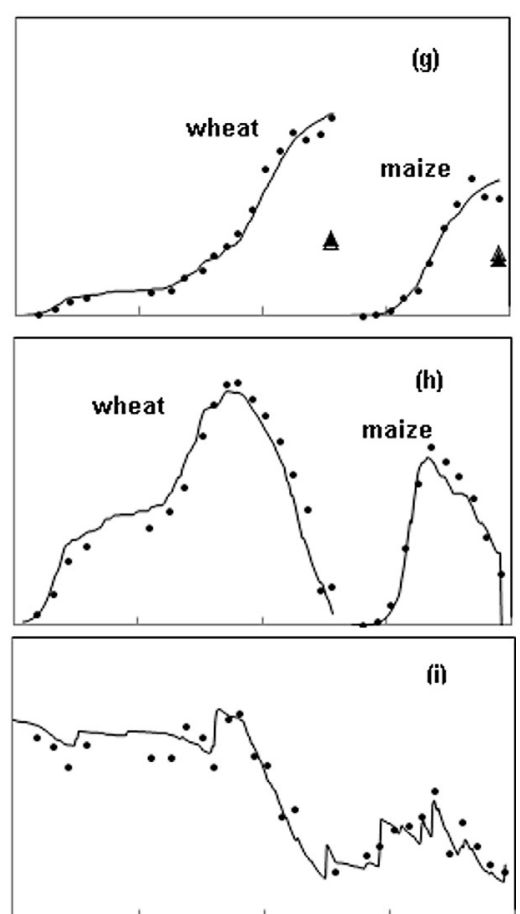

$0810^{107} \quad 0810^{4107} \quad 071070^{707} \quad 0511^{10107}$

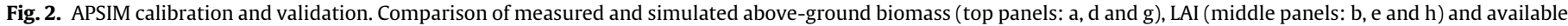

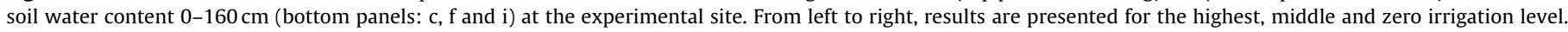
Calibration results (left column) and validation results (middle and right columns).

\section{Materials and methods}

\subsection{Study area}

As a focal area for our simulations, we chose the Taihang mountain foot plain (Hebei), an area within the North China plain (NCP) where agricultural land use is intensive, and water relatively scarce, due to unavailability of irrigation water from rivers. The Taihang mountain foot plain is an alluvial fan, where soils are excellent for farming, and water is available from rainfall or from aquifers. The university farm of the Agricultural University of Hebei, Xinji County $\left(37.54^{\circ} \mathrm{N}, 115.12^{\circ} \mathrm{E}\right)$, is located in the alluvial plain of the Taihang Mountain in the northwest of the Hebei plain, which is the area with the most serious water shortage in NCP. The climate is a continental monsoon characterised by cold and dry winters, windy springs, hot and rainy summers and clear autumns. Long term average annual rainfall is $533 \mathrm{~mm}$. Due to the summer monsoon, most precipitation (65-80\%) occurs in summer, with $10-15 \%$ falling in each of spring and autumn and only $2 \%$ in winter (Liang et al., 2011). Weather data were from the weather station in Shijiazhuang $\left(38.03^{\circ} \mathrm{N}, 114.26^{\circ} \mathrm{E}\right)$, at $60 \mathrm{~km}$ from the experimental site. For this station a complete times series starting from 1961 is available from the website of China Meteorological Administration (http:// www.cma.gov.cn/2011qxfw/2011qsjgx/). The Angstrom equation was used to calculate the daily global solar radiation from sunshine hours with $a=0.18$ and $b=0.55$. Trends in weather in the study area have previously been described (Wang et al., 2008). A small belowground net lateral inflow ( $\Delta L=16 \mathrm{~mm} /$ year) coming from the mountains in the west was taken into account (Zhang et al., 2009). Previously, Kendy (2000) for a study area in the same region also showed that net lateral inflow is of minor importance for the water budget.

\subsection{Agronomic options for groundwater saving}

We defined cropping systems with different cropping intensities (cropping intensity is the long term average number of crops per year), with or without water saving technologies (plastic film), and using different irrigation strategies.

Transpiration $T$ can be reduced by growing less crops (for example 3 crops in 2 years or example one crop per year instead of the current practice of two crops per year), use shorter duration crops (Tao et al., 2014) and use crops that transpire less (Yang et al., 2015b). Given the dominance of wheat and maize we did in this paper not consider shifting to other crops. Although not planting a crop leads to a large drop in production, it also has advantages that are often not considered. Part of the water not transpired (the part not lost to transpiration) is retained as increased soil moisture, either in the layers that can be accessed by the crop or in deeper layers, where it will eventually contribute to the groundwater reserves. Thus part of the fallow rainfall becomes available to the next crop. Yield and profit of a single, well watered crop may be higher than that of two poorly watered crops. Hence, water use must be optimised across multiple seasons, including the fallow period, rather than for individual crops. Hence, we calculate the water productivity of the system, WP, as $\Sigma Y / \Sigma(E+T)$ where $Y$ is the total grain production and summation is over the full 50 years period including the fallow periods.

Water consumption can be reduced by managing evaporative losses $(E)$. A technique which is gaining popularity in China is the use of plastic film to cover the soil (Deng et al., 2006; Espí et al., 2006; Zhang et al., 2005; Xu et al., 2015; Yang et al., 2015a). Plastic film has two effects (1) it reduces evaporation, $E$, and (2) it raises soil temperature. Both effects stimulate crop growth and production. Both effects were also included in our model (see Appendix for further details). Experiments are ongoing with different fractions 
of soil cover with plastic film. In our simulations we considered the case where plastic reduces soil evaporation by 50 or $100 \%$. Soil evaporative losses are largest during periods with high soil moisture content, high temperatures and low soil coverage by leaf area. Soil coverage in winter wheat is low during the cold and dry winter period when evaporation potential is low. Highest potential savings in evaporation by using plastic film are therefore expected in the spring/summer period when maize is grown. Moreover, application of plastic is practically easier in maize than in wheat. We therefore only simulated plastic film in the maize crop.

Finally, for each system (i.e. a crop sequence with or without plastic film), we iteratively determined the level of irrigation input at which the system was groundwater neutral in the long run. Irrigation rules were developed to optimize amount and timing of irrigation input. These rules state that if on any day during a critical stage of crop growth the soil moisture content in the root zone drops below a critical level $\theta_{c}$, irrigation is applied to replenish soil moisture content to level $\theta^{*}$. The rules were optimized to obtain maximum grain yield while maintaining groundwater neutrality. Each system has its own values of $\theta_{\mathrm{c}}$ and $\theta^{*}$, which we define below.

\subsection{APSIM calibration and validation}

Under water limited conditions, yield increases linearly with transpiration. Still we may find large differences in yield for any given level of transpiration, caused by the timing and severity of drought spells. Furthermore, yields in subsequent seasons are linked through water storage in the soil. To capture these drought stress effects in the plant and allow multi-year simulations, we chose to use a model with accurate representation of physiological responses to drought and a soil water balance that can be simulated continuously from one year to the other, also during fallows. The APSIM model (Keating et al., 2003) has been developed especially for semi-arid environments and has been extensively validated for wheat (Asseng et al., 1998a,b; Probert et al., 1998) and maize (Nelson et al., 1998), also in the North China Plain (Chen et al., 2010a,b; Liu et al., 2010). The model simulates crop growth and the soil water balance and can simulate a sequence of different crops with intermittent fallow periods. We used APSIM version 7.4 and the SOILWAT water balance module. Details on model calibration and validation can be found in Appendix.

\subsection{APSIM simulations}

Simulations on crop performance and water use in alternative scenarios were simulated using the APSIM model. We assumed absence of weeds, no pests and diseases and no nutrient limitations. To ensure no nutrient limitations occurred we applied (in the simulations) high amounts of $\mathrm{N}$ fertiliser (effects of other nutrients are not included in the model). The results presented therefore represent the highest attainable yields under water limitation. Optimising fertiliser application rates or minimising environmental impacts of excessive fertiliser was beyond the scope of this paper. Irrigation was adjusted in the groundwater neutral systems as described above. We considered different cropping intensities to reduce $T$ and included scenarios with plastic film in maize to reduce evaporation $(E)$. For single maize we considered the conventional summer maize crop and an improved maize crop sown earlier in the year at higher than normal density and with improved yielding ability. In all the scenarios, the simulated sowing time of wheat was 12 October. Summer maize was sown on 10 June and spring maize on 15 May. When growing one crop per year the crops were harvested at physiological maturity. In the simulations with two crops per year, occasionally a crop was harvested when not yet mature, to allow for timely sowing of the next crop. Harvesting the crop when not yet completely mature occurs also in reality; it is unavoid- able with the tight schedule of continuously growing two crops per year in the double cropping system. Sowing densities were 490 plants $\mathrm{m}^{-2}$ for wheat, and 7 plants $\mathrm{m}^{-2}$ for both summer and spring maize. These values are representative for current agronomic practices (Liang et al., 2011). Four kinds of scenarios were simulated: (i) current irrigation practice (scenarios 1a-3a), (ii) ground water neutral, (iii) zero irrigation, (iv) selected cropping systems in one climate change scenario. For the most promising cropping systems we checked whether our results would be affected by climate changes predicted for the $2060 \mathrm{~s}$, assuming a $\mathrm{CO}_{2}$ concentration of $632 \mathrm{ppm}$ and an increase of maximum and minimum temperature with $3.3^{\circ} \mathrm{C}$ and $3.8^{\circ} \mathrm{C}$ respectively (Guo et al., 2010). All grain yields are expressed in tons of dry matter per hectare.

Within these main groups of scenarios, eight different crop systems were tested. Table 1 describes the simulated cropping systems. Ground water neutral scenarios $1 \mathrm{~b}-3 \mathrm{~b}$ are based on the current practice scenarios $1 \mathrm{a}-3 \mathrm{a}$, with still two crops per year and only the irrigation input reduced. In scenarios $4 \mathrm{~b}-8 \mathrm{~b}$ we reduce the number of crops grown per year, thus lowering transpiration and increasing the amount of water available per crop. We consider scenarios with one crop per year, 3 crops in two years and an opportunistic scenario in which a second crop is only grown if enough water is available in the soil profile at the start of the growing season (opportunity cropping). The irrigation amount is adjusted to a level at which the crop system becomes ground water neutral. That is where $\Sigma I=\Sigma(D+\Delta L)$, and summation is over 50 simulated years. The timing of irrigation was matched to the most sensitive stages of wheat and maize. Table 1 describes in detail the cropping systems, their irrigation timing and amounts.

\subsection{Summary statistics}

We calculated summary statistics for each cropping system by averaging total water flows $(I, R, \Delta L, E, T, D)$ over the simulated period of 50 years. We summarised these to annual averages. Changes in the groundwater table were calculated as:

$\Delta \mathrm{GWT}=0.001 \times \frac{\Sigma(D+\Delta L-I)}{\mu}$

where $\Delta \mathrm{GWT}$ is the change in groundwater table depth (m/year); $D$ is drainage ( $\mathrm{mm} /$ year), $I$ is irrigation ( $\mathrm{mm} /$ year $), \Delta L(\mathrm{~mm} /$ year $)$ is net lateral (external) recharge, 0.001 is for conversion from $\mathrm{mm}$ to $\mathrm{m}$ and $\mu$ is the specific yield (amount of pore space in the underground that can be filled with water) which we set to 0.15 based on (Guo et al., 2010).

\section{Results}

\subsection{APSIM calibration and validation}

After calibration, the model described 95\% of the variation in wheat and maize biomass, $90 \%$ of variation in LAI, $84 \%$ of variation in soil water content during the whole year, and $82 \%$ of the variation in crop grain yields under different irrigation practices in different years. The RMSE of simulated as compared to measured biomass, LAI, available soil water content and grain yield was $0.88 \mathrm{tha}^{-1}, 0.72,27 \mathrm{~mm}$ and $0.64 \mathrm{tha}^{-1}$, respectively. The obtained parameter values and resulting accuracies are consistent with other studies using APSIM for wheat and maize simulation in the NCP (Wang et al., 2008). Fig. 2 shows calibration results (left column) and validation results (middle and right columns).

\subsection{Groundwater neutral irrigation and cropping systems}

Groundwater table would decline on average $1.6 \mathrm{~m} /$ year under current practice, would remain constant (by design) in the ground- 
Table 1

Key agronomic characteristics of the simulated cropping systems.

\begin{tabular}{|c|c|c|}
\hline & Current practice & Description \\
\hline $1 \mathrm{a}$ & $\begin{array}{l}\mathrm{CP} \text { (wheat maize } \\
\text { double cropping) }\end{array}$ & $\begin{array}{l}\text { Wheat/maize double cropping, with irrigation of } 345 \mathrm{~mm} \text { according to farmer's practice, distributed as } 75 \mathrm{~cm} \text { water at } \\
\text { sowing, } 75 \mathrm{~cm} \text { at stem extension, and } 75 \mathrm{~cm} \text { at flowering in wheat, and } 60 \mathrm{~mm} \text { at sowing and } 60 \mathrm{~mm} \text { at flowering in } \\
\text { maize. Total irrigation: } 345 \mathrm{~mm}\end{array}$ \\
\hline $2 a$ & $\begin{array}{l}\text { CP-f50 (plastic film } \\
\text { blocking } 50 \% \text { of } \\
\text { evaporation) }\end{array}$ & $\begin{array}{l}\text { Current practice with plastic film blocking } 50 \% \text { of the evaporation and increasing the temperature both from sowing } \\
\text { to silking in the maize crop }\end{array}$ \\
\hline $3 a$ & $\begin{array}{l}\text { CP-f100 (plastic } \\
\text { film blocking } 100 \% \\
\text { of evaporation) }\end{array}$ & $\begin{array}{l}\text { Current practice with plastic film blocking } 100 \% \text { of the evaporation and increasing the temperature both from sowing } \\
\text { to silking in the maize crop }\end{array}$ \\
\hline $1 b$ & $\begin{array}{l}\text { Groundwater neutral } \\
\text { WM (wheat maize } \\
\text { double cropping) }\end{array}$ & $\begin{array}{l}\text { If average soil water content in the top } 120 \mathrm{~cm} \text { is below } 60 \% \text { of field capacity at wheat sowing, then irrigate to } 70 \% \text { of } \\
\text { field capacity; no irrigation in maize }\end{array}$ \\
\hline $2 b$ & WM-f50 & $\begin{array}{l}\text { If average soil water content in the top } 120 \mathrm{~cm} \text { is below } 70 \% \text { of field capacity at wheat sowing, then irrigate to } 85.5 \% \text { of } \\
\text { field capacity; no irrigation in maize. Plastic film cover in maize reduces evaporation by } 50 \% \text { and increases } \\
\text { temperature both from sowing to silking }\end{array}$ \\
\hline $3 b$ & WM-f100 & $\begin{array}{l}\text { If average soil water content in the top } 120 \mathrm{~cm} \text { is below } 70 \% \text { of FC, then irrigate to increase soil moisture to } 86.5 \% \text { of } \\
\text { FC; no irrigation for maize. Plastic film cover in maize reduces evaporation by } 100 \% \text { and increases temperature both } \\
\text { from sowing to silking }\end{array}$ \\
\hline $4 b$ & W (wheat only) & $\begin{array}{l}\text { If average soil water content in the top } 120 \mathrm{~cm} \text { is below } 80 \% \text { of field capacity at wheat sowing, } 80 \% \text { of field capacity at } \\
\text { the start of flowering or } 80 \% \text { of field capacity at grain filling, then increase soil water content to } 95 \%, 100 \text { and } 100 \% \text { of } \\
\text { field capacity, respectively }\end{array}$ \\
\hline $5 b$ & $\begin{array}{l}\text { M (summer maize } \\
\text { only) }\end{array}$ & $\begin{array}{l}\text { If average soil water content in the top } 120 \mathrm{~cm} \text { is below } 80 \% \text { of field capacity at maize sowing, or at the start of } \\
\text { flowering or grain filling, then increase soil water content to } 100 \%, 100 \% \text { and } 100 \% \text { of field capacity }\end{array}$ \\
\hline $6 b$ & $\begin{array}{l}\text { Ms (spring maize } \\
\text { only) }\end{array}$ & $\begin{array}{l}\text { If average soil water content in the top } 120 \mathrm{~cm} \text { is below } 70 \% \text { of field capacity at maize sowing time or at the start of } \\
\text { flowering or grain filling, then increase soil water content to } 86.5 \%, 70 \% \text { and } 70 \% \text { of field capacity, respectively }\end{array}$ \\
\hline $7 b$ & $\begin{array}{l}\text { Ms/WM } \\
\text { (wheat/maize } \\
\text { double cropping, } \\
\text { alternating with } \\
\text { spring maize) }\end{array}$ & $\begin{array}{l}\text { Always grow summer maize. If soil water content is below } 65 \% \text { field capacity at maize sowing, then irrigate to } 69 \% \\
\text { field capacity. Sow wheat only if at wheat sowing time (12 October) soil water content is more than } 75 \% \text { field capacity. } \\
\text { In years in which wheat is grown, irrigate wheat to } 85 \% \text { field capacity at jointing if soil water content is below } 75 \% \\
\text { field capacity }\end{array}$ \\
\hline \multirow[t]{3}{*}{$8 b$} & $\begin{array}{l}\text { WoM } \\
\text { (Maize + opportunity } \\
\text { cropping of wheat) }\end{array}$ & $\begin{array}{l}\text { Three harvests in two years (spring maize in the first year, winter wheat-summer maize in the second year, Ms/WM). } \\
\text { Irrigation for wheat: if soil water content is below } 70 \% \text { field capacity at sowing, then irrigate to } 72 \% \text { field capacity. } \\
\text { Irrigation for spring maize: if soil water content is below } 70 \% \text { field capacity at sowing, then irrigate to } 73 \% \text { field } \\
\text { capacity. No irrigation for summer maize }\end{array}$ \\
\hline & Zero irrigation & $\begin{array}{l}\text { The zero irrigation scenarios } 1 \mathrm{c}-8 \mathrm{c} \text { were specified identically to the ground water neutral scenarios } 1 \mathrm{~b}-8 \mathrm{~b} \text {, but } \\
\text { without irrigation }\end{array}$ \\
\hline & Climate change & $\begin{array}{l}\text { Climate change scenarios (Appendix, } \S 2 \text { ) were identical in crop choice and irrigation to current practice scenarios } 1 \mathrm{a} \\
\text { and } 3 \mathrm{a} \text {, and ground water neutral scenarios } 1 \mathrm{~b}, 3 \mathrm{~b}, 4 \mathrm{~b} \text { and } 6 \mathrm{~b} \text {, but had changed climate. }\end{array}$ \\
\hline
\end{tabular}

water neutral systems and rise by $0.3-0.5 \mathrm{~m} /$ year under zero irrigation (Table 2, Fig. 3). We first present results for the cropping systems without plastic mulch. Under current practice total yield without plastic mulch is $15.5 \mathrm{tha}^{-1}$ (Table 2, 1a). The highest groundwater neutral total grain yield per year (maize + wheat) without plastic mulch is $9.3 \mathrm{tha}^{-1}$ (Table 2, 6b), $40 \%$ lower than under current practice. Highest zero-irrigation yield is $50 \%$ lower than current yields (Table 2, 1c), and the most productive system in terms of grain yield would be one with maize only (Table 2: $5 c, 6 c)$. The irrigations applied in the groundwater neutral simulations prevent complete crop-failure and can be considered "life saving". Complete crop-failures of wheat occur frequently (once every five years) during winter droughts in the zero-irrigation scenario while in the groundwater neutral simulations wheat yields are never below $1.5 \mathrm{tha}^{-1}$ (Fig. 4). Groundwater neutral and zeroirrigation scenarios differ little with respect to maize yield as this crop is grown during the comparatively wet summers (Fig. 5).

Simulations of current practice produce an average groundwater level decline of $1.6 \mathrm{~m} /$ year and an increase of around $0.4 \mathrm{~m} /$ year under zero-irrigation. With a cropped area of $80 \%$ of Hebei province (Yang et al., 2007), a rough estimate of Hebei groundwater decline is $0.8 \times 1.6-0.2 \times 0.4=1.2 \mathrm{~m} /$ year (assuming all cropped area is irrigated and all non-cropped area is not irrigated). These numbers are in agreement with, yet somewhat higher than scarce available data on actual groundwater decline (Zhang et al., 2003; Currell et al., 2012; Lu et al., 2011). Fig. 3 shows what would have happened in the scenario if the current practice of wheat-maize cropping with $345 \mathrm{~mm}$ irrigation were practiced 50 years long, in all the area.
In reality not the whole region was under double cropping in the last 50 years and in reality historical irrigation amounts may have been lower. Therefore the $1.6 \mathrm{~m} /$ year rate of groundwater decline under current practice is larger than the observed historical trend of around $-0.8 \mathrm{~m} /$ year observed by Zhang et al., 2003. To make a more accurate estimate of regional changes in groundwater, historical data on land use, cropping intensity and irrigation practices would need to be included. While our estimate of groundwater extraction is on the high end, it seems likely that for the future this is the more realistic estimate, given projections in demand for food crops, current land use and current irrigation practices.

\subsection{Plastic film}

Soil cover with plastic film in maize increases yield and reduces evaporation. Groundwater decline is reduced from 1.6 to $1.3 \mathrm{~m} /$ year under current irrigation practice (Table 2, 1a-3a), thus plastic alone is insufficient to make the system groundwater neutral. Using plastic mulch would mitigate the yield reductions from the transition from current practice to groundwater neutral. These reductions would be $21 \%$ and $33 \%$ when plastic film blocks respectively $100 \%$ and $50 \%$ of evaporation, compared to $44 \%$ without plastic mulch (Table 2, 1b-3b). Without plastic film, the most productive groundwater neutral system is single spring maize with an average annual production of $9.3 \mathrm{tha}^{-1}$ (Table 2, 6b). When mulching with plastic film is adopted, groundwater neutral production is higher with two crops, with total production of 10.3 and $12.3 \mathrm{tha}^{-1}$ assuming a 50 or $100 \%$ reduction in evaporation, respectively ( $2 \mathrm{~b}, 3 \mathrm{~b})$. 


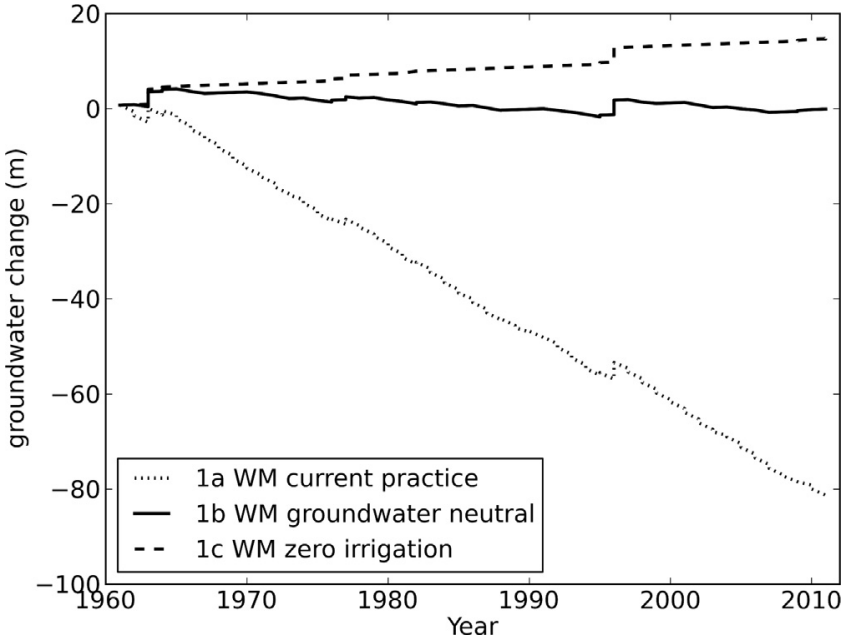

Fig. 3. Simulated change in groundwater level in wheat-maize double cropping under current practice, with groundwater neutral irrigation, and without irrigation, over a period of 50 years. Jumps in 1963 and 1996 are due to very large rainfall in these years, but have overall little effect on the trends shown. The figure shows not actual groundwater levels, but change relative to the start year of the simulation in 1961. Note that this figure shows scenarios, not predictions of actual groundwater level trends. It shows what would have happened if the current practice of wheat-maize rotations with $345 \mathrm{~mm}$ irrigation were practiced all 50 years. If for example in the past cropping intensity and irrigation amounts were lower, groundwater decline would be less. The figure shows groundwater change for an area under double cropping. If in parts of the region only one crop or zero crops are grown, then regional groundwater decline would also be less. An historical analysis of land use change was beyond the scope of this paper. What this figure does show is what would happen if the cropping systems defined in Table 1 were practiced 50 years long.

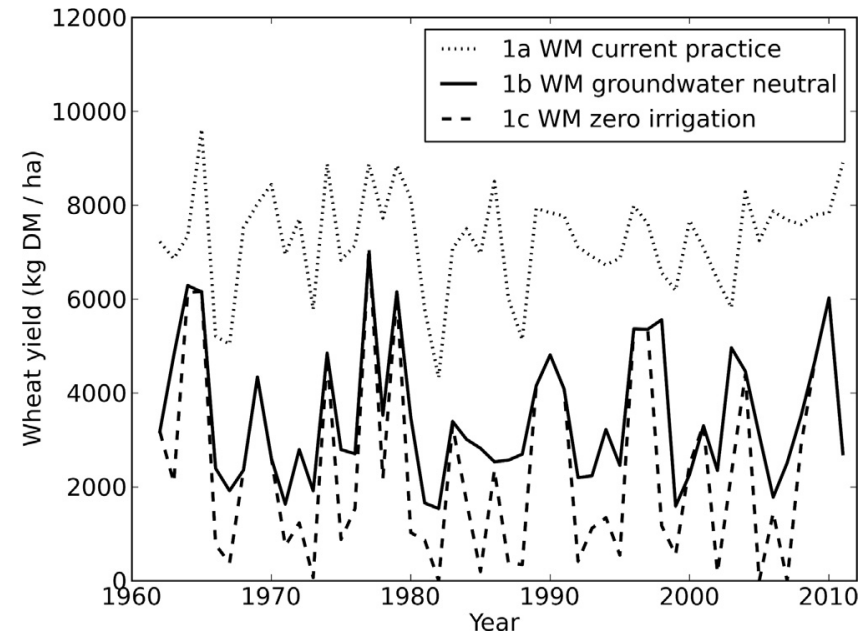

Fig. 4. Simulated wheat yields in wheat-maize double cropping under current practice, with groundwater neutral irrigation, and without irrigation, over a period of 50 years. $Y$-axis shows yield in kilogram dry matter per hectare.

\subsection{Climate change}

Climate change resulted in minor total yield reductions compared to current yields and a continuation of groundwater decline if current irrigation practices were continued (Appendix, Table T5). Simulated maize yields decreased and wheat yields increased, both by around $20 \%$. Highest future productivity would be obtained with $100 \%$ reduction of evaporation by plastic mulch. Without plastic cover the most productive groundwater neutral system changed from spring maize to winter wheat. These simulations indicate that climate change would slightly worsen the current water crisis. Broadly, however, current and future water issues are similar.

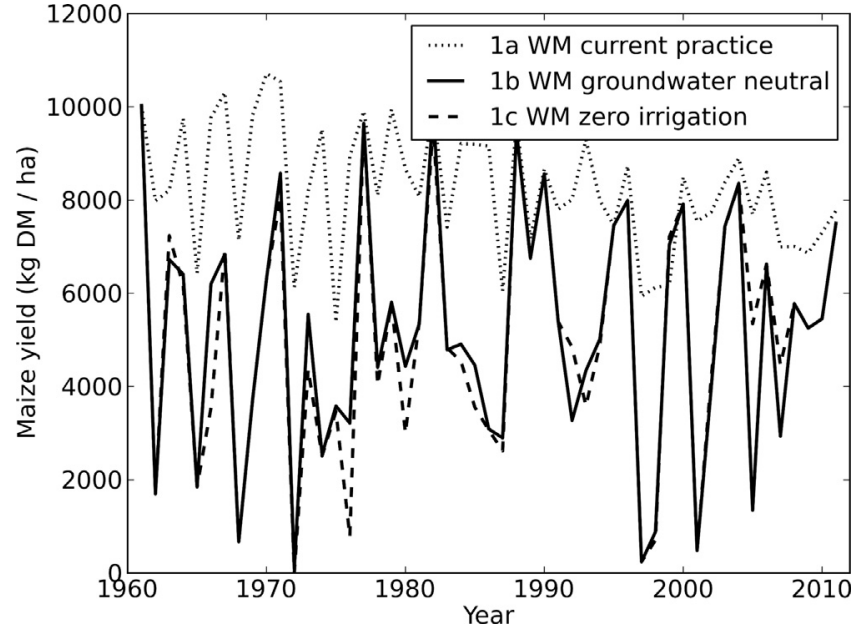

Fig. 5. Simulated maize yields in wheat-maize double cropping under current practice, with groundwater neutral irrigation, and without irrigation, over a period of 50 years. Note: failure of the preceding wheat crops (Fig. 2) conserved water in the soil, supporting a higher maize yield with zero irrigation than with groundwater neutral irrigation in 2005 and 2007.

Without adaptation, groundwater will continue to decline and total productivity would slightly decrease.

\section{Discussion}

We quantified agricultural adaptation options for grain cultivation in the North China Plain to stop the fall of water tables and avoid a looming water crisis. The analysis indicates that at current levels of water supply, crop systems need to be drastically adapted, primarily by reducing water input, but also by using technology that can enhance the efficiency of water use. The simulations indicate that omitting wheat is an effective way of reducing water inputs at the system level. Omitting wheat from the system will affect food production and farm income, and is therefore no easy adaptation. An alternative could be to switch from growing two cereals (this paper) to cereal-vegetable systems (Yang et al., 2015b). We did not explore that option because of the importance of the NCP for cereal production and because this option was already explored by Yang et al. (2015b). A debate with all stakeholders will be needed to explore options that are socially acceptable and how these can be supported by institutions (Shen, 2015).

Below, we reflect on the broader applicability of the approach, the uncertainties and the implications of the work presented in this paper.

\subsection{Applicability of the approach in other parts of the NCP}

Although the problem of groundwater decline exists throughout the NCP, our study focused on an area where groundwater decline is most severe, in the Hebei province. The region can be defined as the alluvial fan plains at the mountain foot (south of the Yanshan Mountains and east of the Taihang Mountains). In this region the groundwater decline is large due to the high cropping intensity, lack of access to river irrigation water, low rainfall and no practical impediments as yet to groundwater uptake (a shallow aquifer and no salinity problems). Groundwater pumping and groundwater recharge is more complex in two other regions: the (more eastern) alluvial plains and the coastal plains. The alluvial plains are composed of multiple aquifers. Moreover, aquifers within $100 \mathrm{~m}$ below the surface are primarily saline. Hence, irrigation water is sourced mainly from deep aquifers ( $>150 \mathrm{~m}$ depth). Due to the weak recharge of freshwater for such kind of deep aquifers, its 
recharge relies heavily on mountain-foot confined water (i.e. Taihang Mountain). The coastal plains are short of fresh groundwater. All groundwater is saline due to its vicinity to the sea. Water for irrigation purposes comes exclusively from surface water in river channels.

Groundwater recharge through drainage below the root zone (as we suggested in this paper) may not work under conditions where it first has to pass through saline soil layers (alluvial plains) or where it may increase salinity problems caused by the rising saline groundwater table (coastal plains). The proposed solution might work in the Yellow-River-Vicinity regions. Here groundwater is more plentiful and the recharge is mainly from the Yellow River. Nevertheless, groundwater in these regions is also declining and here as well a shift to more sustainable groundwater use is needed. With river irrigation water available the yield penalty for shifting to a groundwater neutral system will be less big than for the Alluvial Fan Plain on which we concentrated in our analysis.

\subsection{Uncertainties in current and future water supply and demand}

Below, we discuss uncertainties in current and future water supply and demand. Perhaps the largest uncertainty is on the supply side. It is clear that current extraction rates cannot continue forever, but it is unknown how much time it will take before extraction becomes impossible, physically, economically or in terms of quality of the remaining groundwater. We experienced great difficulty estimating surface and subsurface flow of water coming from the western mountain ranges. Upscaling would benefit from more accurate quantification of this source of water supply.

Future external water input may come from the South to North Water Transfer (SNWT) Project (Berkoff 2003; Cao et al., 2013; Yang et al., 2010). This $\$ 62$ billion project aims at diverting water from the southern Danjiangkou reservoir through the NCP to Being through a $1264 \mathrm{~km}$ long canal. The project was completed in 2014 and will be delivering $\sim 3.0 \mathrm{~km}^{3} /$ year to the Hebei Plain (Cao et al., 2013), which with an area of $73,100 \mathrm{~km}^{2}$ (excl Beijing and Tianjian) leads to an additional lateral inflow of $10^{6} \times 3.0 / 73,100=41 \mathrm{~mm} /$ year. According to our simulations, a $242 \mathrm{~mm}$ increase in water supply would be needed to become groundwater neutral at current rates of irrigation (Table 2, $1 \mathrm{a}, I-D-L$ ). Thus the SNWT project will ease the pain but it will be insufficient to halt the water decline.

\subsection{Sustainability}

Sustainability is broader than only groundwater neutrality. It involves other environmental and socio-economic indicators. Below, we discuss our results in relation to the environmental impacts of plastic and the socio-economic viability of double cropping in the (lower yielding) groundwater neutral scenarios.

Current practices of plastic film cover result in 50\% reduction in evaporation (Zhang et al., 1999) but further technological development (Gan et al., 2013) may still increase this percentage. The environmental costs need to be considered, especially when nonbiodegradable plastics are used (Chiellini et al., 2002). According to our simulations, using plastic film may ease the pain of becoming more sustainable in terms of ground water use, with a yield penalty that is less than without plastic film. Widespread adoption of plastic film mulching may well create a new environmental problem, as the plastic rips and fragments over time and many small particles accumulate in the soil. This is already witnessed in NCP and Xinjiang regions (Yan et al., 2006; He et al., 2009). It is often said that biodegradable plastics are too expensive in comparison with the non-degradable plastics. The problem with a comparison of the prices of these two sorts of plastics is that it only considers the production costs of the plastics and not the environmental costs of plastic pollution. Biodegradable plastic can be produced out of wheat and maize straw (Alun et al., 2012; Pradhan et al., 2010; Yang et al., 2015a), which is abundant in the North China Plain. This straw is now incorporated into the soil, left on the surface as mulch, or burnt to eliminate pathogens in the straw. Straw could also be used as a resource for production of biodegradable plastic. Logistics, energy consumption and financial aspects of collecting and processing the straw and redistributing plastics are important issues to be resolved. But in principle there are sustainable alternatives for non-degradable oil based plastics. Further research on these issues is needed.

Growing two crops is costlier than growing one crop. Labour is already becoming scarce in the countryside due to rapid growth off-farm employment (Qiang et al., 2013). Growing two crops will only be attractive if the yield gain is large enough to compensate for the extra costs, including costs of labour. Double cropping with plastic film cover is more productive (12.1 or $10.3 \mathrm{tha}^{-1}$ ) than cultivating spring maize only $\left(9.3 \mathrm{tha}^{-1}\right)$ in the groundwater neutral simulations. Whether double cropping with plastic film is also more profitable remains to be investigated. Further economic analysis should also consider the value of crop residues, which can be used as fodder for animals or to maintain soil fertility.

\subsection{Future outlook}

According to UN projections, Chinese population will increase further from $1.40 \times 10^{9}$ now to around $1.45 \times 10^{9}$ in 2030 , after which population would decline again (United Nations, 2014). Food demand will increase mainly due changing consumption patterns. With increasing wealth, meat and milk consumption generally increase, which would greatly affect water demand, as the water footprint of livestock is much larger than that of grains (Hoekstra and Chapagain, 2007). How consumption patterns will change depends on the magnitude of future economic developments. In summary, food and therefore also water demand is likely to increase, while our analysis shows that to become more sustainable, a drastic reduction in water use is needed. The water problem may therefore get worse in the future. Three main options exist to cope with the looming groundwater crisis: (1) import water from the south of China where it is more abundant (the SNWT project), although as we showed the SNWT can fill only a small part of the gap in current water demand; (2) import food (Brown, 1995; Brown and Halweil, 1998; Huang et al., 2010; Dalin et al., 2012; Carr et al., 2013); (3) promote diets with limited meat and milk consumption. Another option is laissez faire and continue groundwater depletion in the hope that technological developments and declining population growth might come to the rescue. While the latter "solution" seems merely wishful thinking, the actual solution to the problem is probably a matter of "many little hammers". For example, it would be interesting to explore regional scenarios where in part of the region groundwater neutral cereal double cropping (this paper) is applied and in part of the region cereal vegetable cropping (Yang et al., 2015b), with the region as a whole being groundwater neutral.

\section{Conclusions}

The current practice of groundwater overexploitation is not sustainable. It is unclear how long the current practice of overexploitation can continue, but once it comes to an end, consequences will be grave. Our paper shows that once groundwater is no longer physically or economically extractable, yields will be on average $50 \%$ lower than under current practice and years with complete crop failure for the wheat crop would increase from non-occurrence (current practice and groundwater neutral) to once in every five years (zero irrigation scenarios). A transition to groundwater neutral cropping systems also causes large yield decline relative to 
Table 2

Key agronomic characteristics of the simulated cropping systems.

\begin{tabular}{|c|c|c|c|c|c|c|c|c|c|c|c|c|}
\hline & \multirow[b]{2}{*}{ Cropping system } & \multicolumn{3}{|c|}{ Yield (t DM/ha/year) } & \multicolumn{4}{|c|}{ Water flows (mm/year) } & \multicolumn{3}{|c|}{$W P=$ Yield $/(E+T)(\mathrm{kg} / \mathrm{ha} / \mathrm{mm})$} & \multirow[t]{2}{*}{ Net groundwater change (m/year) ${ }^{-}$} \\
\hline & & Wheat & Maize & Total & I & $D$ & E & $T$ & Wheat & Maize & Total & \\
\hline & Current pactice & & & & & & & & & & & \\
\hline $1 \mathrm{a}$ & $\mathrm{CP}$ (wheat maize double cropping) & 7.3 & 8.3 & 15.5 & 345 & 87 & 200 & 590 & 17.6 & 22.5 & 19.6 & -1.6 \\
\hline $2 \mathrm{a}$ & CP-f50 (plastic film blocking 50\% of evaporation) & 7.5 & 8.6 & 16.1 & 345 & 108 & 152 & 616 & 17.4 & 25.9 & 21.0 & -1.5 \\
\hline \multirow[t]{2}{*}{ 3a } & CP-f100 (plastic film blocking 100\% of evaporation) & 7.7 & 8.9 & 16.5 & 345 & 141 & 102 & 635 & 17.5 & 30.3 & 22.4 & -1.3 \\
\hline & Groundwater neutral & & & & & & & & & & & \\
\hline $1 \mathrm{~b}$ & WM (wheat maize double cropping) & 3.5 & 5.2 & 8.7 & 44 & 28 & 195 & 353 & 14.6 & 17.0 & 15.9 & 0.0 \\
\hline $2 \mathrm{~b}$ & WM-f50 & 3.9 & 6.5 & 10.3 & 47 & 31 & 140 & 407 & 15.0 & 22.7 & 18.9 & 0.0 \\
\hline $3 \mathrm{~b}$ & WM-f100 & 4.6 & 7.7 & 12.3 & 59 & 43 & 78 & 470 & 16.1 & 30.0 & 22.5 & 0.0 \\
\hline $4 \mathrm{~b}$ & W (wheat only) & 7.1 & 0 & 7.1 & 99 & 83 & 234 & 312 & 16.9 & & 13.0 & 0.0 \\
\hline $5 b$ & $\mathrm{M}$ (summer maize only) & 0 & 9.1 & 9.1 & 123 & 107 & 244 & 304 & & 21.9 & 16.7 & 0.0 \\
\hline $6 \mathrm{~b}$ & Ms (spring maize only) & 0 & 9.3 & 9.3 & 74 & 58 & 235 & 313 & & 19.5 & 16.9 & 0.0 \\
\hline $7 \mathrm{~b}$ & Ms/WM (wheat/maize double cropping, alternating with spring maize) & $1.8(3.6)^{\mathrm{a}}$ & 7.0 & 8.9 & 47 & 31 & 216 & 333 & 14.4 & 18.9 & 16.1 & 0.0 \\
\hline \multirow[t]{2}{*}{$8 \mathrm{~b}$} & WoM (Maize + opportunity cropping of wheat) & $1.4(6.5)^{\mathrm{a}}$ & 7.4 & 8.9 & 57 & 41 & 224 & 325 & 17.9 & 20.1 & 16.2 & 0.0 \\
\hline & Zero irrigation & & & & & & & & & & & \\
\hline $1 \mathrm{c}$ & WM & 2.4 & 5.1 & 7.5 & 0 & 28 & 203 & 301 & 13.1 & 16.6 & 14.9 & 0.3 \\
\hline $2 c$ & WM-f50 & 2.8 & 6.5 & 9.3 & 0 & 31 & 144 & 358 & 13.6 & 22.6 & 18.5 & 0.3 \\
\hline $3 c$ & WM-f100 & 3.4 & 7.7 & 11.1 & 0 & 42 & 77 & 413 & 13.8 & 29.9 & 22.6 & 0.4 \\
\hline $4 c$ & W & 5.0 & 0 & 5.0 & 0 & 66 & 238 & 226 & 15.7 & & 10.8 & 0.5 \\
\hline $5 c$ & M & 0 & 7.0 & 7.0 & 0 & 53 & 240 & 240 & & 19.4 & 14.6 & 0.5 \\
\hline $6 c$ & Ms & 0 & 7.8 & 7.8 & 0 & 41 & 235 & 256 & & 19.5 & 15.8 & 0.4 \\
\hline $7 c$ & $\mathrm{Ms} / \mathrm{WM}$ & $1.4(2.8)^{\mathrm{a}}$ & 6.3 & 7.7 & 0 & 32 & 215 & 286 & 13.6 & 18.0 & 15.3 & 0.3 \\
\hline $8 c$ & WoM & $1.1(5.6)^{a}$ & 6.2 & 7.3 & 0 & 35 & 222 & 276 & 17.6 & 18.2 & 14.7 & 0.3 \\
\hline
\end{tabular}

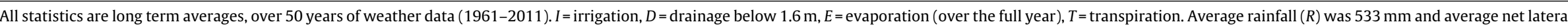
inflow was estimated at $L=16 \mathrm{~mm}$.

A negative value for net groundwater recharge means the groundwater table is going down.

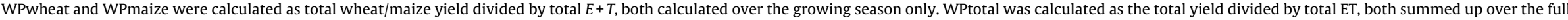

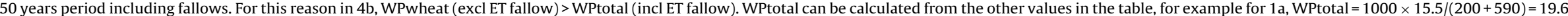

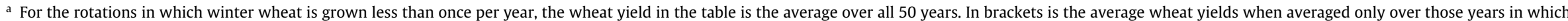
wheat was actually grown. 
current, but less big (44-21\%) than in the case of zero irrigation and without frequent complete yield failures. Careful balancing of the different interests is needed (Shen, 2015), including those of current and future generations. We hope that our study will assist in the design of agronomic and policy options that will ultimately result in more sustainable use of groundwater while also being socially and economically sustainable.

\section{Appendix A. Supplementary data}

Supplementary data associated with this article can be found, in the online version, at http://dx.doi.org/10.1016/j.agwat.2015.11. 005.

\section{References}

Alun, Sun, Z., Jing, Q., Huridun, Yang, C., 2012. Study of microstructure and dynamic mechanical analysis of biodegradable tableware produced with corn straw. Adv. Mater. Res. 380, 160-163.

Asseng, S., Fillery, I.R.P., Anderson, G.C., Dolling, P.J., Dunin, F.X., Keating, B.A., 1998a. Use of the APSIM wheat model to predict yield, drainage, and NO3/leaching for a deep sand. Aust. J. Agric. Res. 49 (3), 363-377.

Asseng, S., Keating, B.A., Fillery, I.R.P., Gregory, P.J., Bowden, J.W., Turner, N.C., Palta, J.A., Abrecht, D.G., 1998b. Performance of the APSIM-wheat model in Western Australia. Field Crops Res. 57 (2), 163-179.

Berkoff, J., 2003. China: the South-North Water Transfer Project-is it justified? Water Policy 5 (1), 1-28.

Bredehoeft, J.D., 2002. The Water Budget Myth revisited: why hydrogeologists model. Groundwater 40 (4), 340-345.

Brown, L.R., 1995. Who will feed China? Wake-up call for a small planet. In: Worldwatch Institute, Environmental Alert Series. W.W. Norton \& Company, Inc, New York, pp. 163.

Brown, L.R., Halweil, B., 1998. China's water shortage could shake world food security. World Watch 11 (4), 10-21.

Cao, G., Zheng, C., Scanlon, B.R., Liu, J., Li, W., 2013. Use of flow modeling to assess sustainability of groundwater resources in the North China Plain. Water Resour. Res. 49 (1), 159-175

Carr, J.A., D’Odorico, P., Laio, F., Ridolfi, L., 2013. Recent history and geography of virtual water trade. PLoS One 8 (2), e55825.

Changming, L., Jingjie, Y., Kendy, E., 2001. Groundwater exploitation and its impact on the environment in the North China Plain. Water Int. 26 (2), 265-272.

Chen, C., Wang, E., Yu, Q., 2010a. Modeling wheat and maize productivity as affected by climate variation and irrigation supply in North China plain. Agron. J. 102 (3), 1037-1049.

Chen, C., Wang, E., Yu, Q., 2010b. Modelling the effects of climate variability and water management on crop water productivity and water balance in the North China Plain. Agric. Water Manage. 97 (8), 1175-1184.

Chiellini, E., Cinelli, P., D’Antone, S., Ilieva, V.I., 2002. Environmentally degradable polymeric materials (EDPM) in agricultural applications-an overview. Polimery 47 (7-8), 538-544.

Condon, A.G., Richards, R.A., Rebetzke, G.J., Farquhar, G.D., 2004. Breeding for high water-use efficiency. J. Exp. Bot. 55 (407), 2447-2460.

Currell, M.J., Han, D., Chen, Z., Cartwright, I., 2012. Sustainability of groundwater usage in northern China: dependence on palaeowaters and effects on water quality, quantity and ecosystem health. Hydrol. Processes 26 (26), 4050-4066.

Dalin, C., Konar, M., Hanasaki, N., Rinaldo, A., Rodriguez-Iturbe, I., 2012. Evolution of the global virtual water trade network. Proceedings of the National Academy of Sciences of the United States of America 109 (16), 5989-5994.

Deng, X.P., Shan, L., Zhang, H.P., Turner, N.C., 2006. Improving agricultural water use efficiency in arid and semiarid areas of China. Agric. Water Manage. 80, 23-40.

Devlin, J.F., Sophocleous, M., 2005. The persistence of the water budget myth and its relationship to sustainability. Hydrogeol. J. 13, 549-554.

Espí, E., Salmerón, A., Fontecha, A., García, Y., Real, A.I., 2006. Plastic films for agricultural applications. J. Plast. Film Sheeting 22 (2), 85-102.

Fang, Q.X., Ma, L., Green, T.R., Yu, Q., Wang, T.D., Ahuja, L.R., 2010. Water resources and water use efficiency in the North China Plain: current status and agronomic management options. Agric. Water Manage. 97, 1102-1116.

Gan, Y., Siddique, K.H.M., Turner, N.C., Li, X.-G., Niu, J.-Y., Yang, C., Liu, L., Chai, Q., 2013. Ridge-furrow mulching systems-an innovative technique for boosting crop productivity in semiarid rain-fed environments. Adv. Agron. 118, 429-476.

Giordano, M., 2009. Global groundwater? Issues and solutions. Annu. Rev. Environ. Resour. 34, 153-178.

Gleick, P.H., Palaniappan, M., 2010. Peak water limits to freshwater withdrawal and use. Proceedings of the National Academy of Sciences of the United States of America 107 (25), 11155-11162.

Guo, R., Lin, Z., Mo, X., Yang, C., 2010. Responses of crop yield and water use efficiency to climate change in the North China Plain. Agric. Water Manage. 97 (8), 1185-1194.
He, W., Yan, Ch., Zhao, C., Chang, R., Liu, Q., Liu, Sh., 2009. Study on the pollution by Plastic mulch film and it's countermeasures in China. J. Agro Environ. Sci. 28 (3), 533-538.

Hoekstra, A.Y., Chapagain, A.K., 2007. Water footprints of nations: water use by people as a function of their consumption pattern. Water Resour. Manage. 21 (1), 35-48.

Howden, S.M., Soussana, J.-F., Tubiello, F.N., Chhetri, N., Dunlop, M., Meinke, H., 2007. Adapting agriculture to climate change. Proceedings of the National Academy of Sciences of the United States of America 104 (50), 19691-19696.

Huang, J., Yang, J., Rozelle, S., 2010. China's agriculture: drivers of change and implications for China and the rest of world. Agric. Econ. 41 (11), 47-55.

Keating, B.A., Carberry, P.S., Hammer, G.L., Probert, M.E., Robertson, M.J., Holzworth, D., Huth, N.I., Hargreaves, J.N.G., et al., 2003. An overview of APSIM, a model designed for farming systems simulation. Eur. J. Agron. 18 (3-4), 267-288.

Kendy, E., 2002. Hydrologic impacts of water-managemetn policies on the North China Plain: case of Luacheng County, Hebei Province, 1949-2000. In: Ph.D. Diss. Department of Biological and Environmental Engineering, Cornell University, Ithaca, New York.

Kendy, E., 2003. The false promise of sustainable pumping rates. Groundwater 41 (1), 2-4.

Kendy, E., Gérard-Marchant, P., Walter, M.T., Zhang, Y., Liu, C., Steenhuis, T.S., 2003. A soil-water-balance approach to quantify groundwater recharge from irrigated cropland in the North China Plain. Hydrol. Processes 17 (10), 2011-2031.

Kendy, E., Zhang, Y., Liu, C., Wang, J., Steenhuis, T., 2004. Groundwater recharge from irrigated cropland in the North China Plain: case study of Luancheng County, Hebei Province, 1949-2000. Hydrol. Processes 18 (12), 2289-2302.

Liang, W.-L., Carberry, P., Wang, G.-Y., Lü, R.-H., Lü, H.-Z., Xia, A.-P., 2011. Quantifying the yield gap in wheat-maize cropping systems of the Hebei Plain, China. Field Crops Res. 124 (2), 180-185.

Liu, Y., Wang, E., Yang, X., Wang, J., 2010. Contributions of climatic and crop varietal changes to crop production in the North China Plain, since 1980. Global Change Biol. 16 (8), 2287-2299.

Lu, X., Jin, M., van Genuchten, M.T., Wang, B., 2011. Groundwater recharge at five representative sites in the Hebei plain, China. Groundwater 49 (2), 286-294.

Mao, X.S., Jia, J.S., Liu, C.M., Hou, Z.M., 2005. A simulation and prediction of agricultural irrigation on groundwater in well irrigation area of the piedmont of Mt. Taihang, North China. Hydrol. Processes 19 (10), 2071-2084.

Nelson, R.A., Dimes, J.P., Paningbatan, E.P., Silburn, D.M., 1998. Erosion/productivity modeling of maize farming in the Philippine uplands. Parameterising the agricultural production systems simulator. Agric. Syst. 58 (2), 129-146.

Pradhan, R., Reddy, M., Diebel, W., Erickson, L., Misra, M., Mohanty, A., 2010. Comparative compostability and biodegradation studies of various components of green composites and their blends in simulated aerobic composting bioreactor. Int. J. Plast. Technol. 14 (Suppl. 1), 45-50.

Probert, M.E., Dimes, J.P., Keating, B.A., Dalal, R.C., Strong, W.M., 1998. APSIM's water and nitrogen modules and simulation of the dynamics of water and nitrogen in fallow systems. Agric. Syst. 56 (1), 1-28.

Qiang, L., Huang, J., Luo, R., Liu, C., 2013. China's labor transition and the future of China's rural wages and employment. China World Econ. 21 (3), 2-24.

Qiu, J., 2010. China faces up to groundwater crisis. Nature 466 (7304), 308.

Shanahan, T.M., Overpeck, J.T., Anchukaitis, K.J., Beck, W., Cole, J.E., Dettman, D.L., Peck, J.A., Scholz, C.A., King, J.W., 2009. Atlantic forcing of persistent drought in West Africa. Science 324, 377-380.

Shen, D., 2015. Groundwater management in China. Water Policy 17 (1), 61-82.

Sophocleous, M., 2000. From safe yield to sustainable development of water resources-the Kansas experience. J. Hydrol. 235 (1-2), 27-43.

Tao, F., Zhang, Shuai, Zhang, Zhao, Rötter, R.P., 2014. Maize growing duration was prolonged across China in the past three decades under the combined effects of temperature, agronomic management, and cultivar shift. Global Change Biol. 20 (12), 3686-3699.

Tao, F., Yokozawa, M., Hayashi, Y., Lin, E., 2003. Future climate change, the agricultural water cycle, and agricultural production in China. Agric. Ecosyst. Environ. 95 (1), 203-215.

Tao, F., Yokozawa, M., Hayashi, Y., Lin, E., 2005. A perspective on water resources in China: interactions between climate change and soil degradation. Clim. Change 68 (1-2), 169-197.

Theis, C.V., 1940. The source of water derived from wells: essential factors controlling the response of an aquifer to development. Civil Eng. 10, 277-280

United Nations, 2014. World Population Prospects: The 2012 Revision. Population Division of the United Nations Department of Economic and Social Affairs of the United Nations Secretariat, http://esa.un.org/unpd/wpp/index.htm (last accessed 11.06.2014).

Wang, E.L., Yu, Q., Wu, D.R., Xia, J., 2008. Climate, agricultural production and hydrological balance in the North China Plain. Int. J. Climatol. 28 (14) 1959-1970.

Xiong, W., Declan, C., Erda, L., Xu, Y.L., Ju, H., Jiang, J.H., Holman, I., Li, Y., 2009. Future cereal production in China: the interaction of climate change, water availability and socio-economic scenarios. Global Environ. Change Hum. Policy Dimens. 19, 34-44.

Xu, J., Li, C., Liu, H., Zhou, P., Tao, Z., et al., 2015. The effects of plastic film mulching on maize growth and water use in dry and rainy years in Northeast China. PLoS One 10 (5), e0125781, http://dx.doi.org/10.1371/journal.pone.0125781. 
Xue, Y., Wu, J., Ye, S., Zhang, Y., 2000. Hydrogeological and hydrogeochemical studies of salt-water intrusion on the south coast of Laizhou Bay, China. Groundwater 38 (1), 38-45.

Yan, C.R, Mei, X.R., He, W.Q., Zheng, S.H., 2006. Present situation of residue pollution of mulching plastic film and controlling measures. Trans. CSAE 22, 269-272 (in Chinese, with English abstract).

Yang, N., Sun, Z.X., Feng, L.S., Zheng, M.Z., Chi, D.C., Meng, W.Z., Hou, Z.Y., Bai, W., Li, K.Y., 2015a. Plastic film mulching for water-efficient agricultural applications and degradable films materials development research. Mater. Manuf. Processes 30 (2), 143-154.

Yang, P., Shibasaki, R., Wu, W., Zhou, Q., Chen, Z., Zha, Y., Shi, Y., Tang, H., 2007. Evaluation of MODIS land cover and LAI products in cropland of North China plain using in situ measurements and Landsat TM Images. IEEE Trans. Geosci. Remote Sens. 45 (10), 3087-3097.

Yang, X., Chen, Y., Pacenka, S., Gao, W., Ma, L., Wang, G., Yan, P., Sui, P., Steenhuis, T.S., 2015b. Effect of diversified crop rotations on groundwater levels and crop water productivity in the North China Plain. J. Hydrol. 522, 428-438.

Yang, Y., Yang, Y., Moiwo, J.P., Hu, Y., 2010. Estimation of irrigation requirement for sustainable water resources reallocation in North China. Agric. Water Manage. 97 (11), 1711-1721

Zhang, H., Wang, X., You, M., Liu, C., 1999. Water-yield relations and water-use efficiency of winter wheat in the North China Plain. Irrig. Sci. 19 (1), 37-45.

Zhang, X.Y., Pei, D., Chen, S.Y., Sun, H.Y., Yang, Y.H., 2006. Performance of double-cropped winter wheat-summer maize under minimum irrigation in the North China Plain. Agron. J. 98, 1620-1626.

Zhang, X.Y., Pei, D., Hu, C.S., 2003. Conserving groundwater for irrigation in the North China Plain. Irrig. Sci. 21 (4), 159-166.

Zhang, Z., Fei, Y., Zhao, Z., et al., 2009. The evaluation of sustainable utilization of the groundwater in North China Plain. Geological Publishing House, Beijing, pp. P275 (in Chinese)

Zhou, Y., 2009. A critical review of groundwater budget myth, safe yield and sustainability. J. Hydrol. 370 (1-4), 207-213. 